\title{
Analisis Kualitas Pelayanan pada Bagian Akademik Politeknik Sawunggalih Aji Purworejo
}

\author{
Yeni Kristiyan*, dan Danis Imam Bachtiar \\ Politeknik Sawunggalih Aji (POLSA) - Purworejo \\ "Email: yenikristiyan@gmail.com
}

\begin{abstract}
In an educational institution, service is one of the most important things to note. Good service will be a satisfaction for the customer, in this case the students. Sawunggalih Aji Polytechnic is one of the colleges in Purworejo Regency. One of the core services in these colleges is academic services, where the main users are students. The services provided so far there are still some shortcomings related to physical aspects and human resources. To find out how the level of satisfaction of students with academic services is needed a study especially related to several factors including evidence of tangible, reliability, responsiveness, assurance and empathy. The research used was a questionnaire with multiple validity, reliability and linear regression analysis. Result of validity and reliability test, all items are declared valid because result of each test value rhitung > 0,279 and reliable because value of Alpha>0,6. Regression result $Y=1,276+0,195$ tangible $+0,093$ reliability $+0,077$ responsiveness $+0,508$ emphaty + 0,340 assurance. In the F test (Anova) obtained Fcount of 31,426> Ftabel value which means that independent variable together effect to student's satisfaction. While in t test, the variable that has significant effect on student satisfaction is assurance variable with t count 2,953> from ttable value 2.015 and significance value equal to 0.005 .
\end{abstract}

Keywords: service, service quality.

\section{PENDAHULUAN}

Di era globalisasi sekarang ini, kualitas pelayanan dipandang sebagai salah satu alat untuk mencapai keunggulan kompetitif, karena kualitas layanan merupakan salah satu faktor yang menentukan pemilihan sesuatu yang dapat memuaskan pelanggan. Menurut Fandy Tjiptono (Hardyansah, 2011) kualitas adalah (1) kesesuaian dengan persyaratan, (2) Kecocokan dengan pemakaian, (3) Perbaikan berkelanjutan, (4) Bebas dari kerusakan atau cacat, (5) Pemenuhan kebutuhan pelanggan sejak awal dan setiap saat, (6) Melakukan segala sesuatu secara benar, (7) Sesuatu yang bisa membahagiakan pelanggan. Oleh karena itu, sebuah pelayanan prima harus diberikan kepada pelanggan sehingga pelanggan dapat merasakan kepuasan atas pelayanan yang telah diberikan. Berkaitan dengan hal tersebut, sebuah paradigma baru harus diusung dalam sebuah lembaga jasa. Khususnya terkait upaya peningkatan kualitas pelayanan dan pengoptimalan seluruh sumber daya manusia yang ada. Begitu pula dengan fasilitas dan sarana prasarana yang ada untuk memenuhi kebutuhan pelanggan, dalam hal ini tidak terkecuali bagi lembaga yang bergerak di bidang jasa pendidikan seperti perguruan tinggi.

Perguruan tinggi harus mampu memenuhi kebutuhan mahasiswa, sehingga perguruan tinggi perlu meningkatkan kualitas pelayanan melalui evaluasi di dalam perguruan tinggi tersebut. Evaluasi yang dilakukan yaitu upaya perbaikan kualitas perguruan tinggi dan seluruh unsur-unsur yang terkait di dalamnya. Tuntutan terhadap perguruan tinggi saat ini bukan hanya sebatas kemampuan untuk menghasilkan lulusan yang baik diukur berdasarkan prestasi akademik semata, melainkan keseluruhan program pelayanan dari lembaga perguruan tinggi, salah satunya adalah pelayanan akademik yang diberikan kepada mahasiswa. Mahasiswa merupakan pelanggan primer sebuah perguruan tinggi, oleh karena itu kepuasan mahasiswa merupakan misi yang harus diwujudkan apabila suatu lembaga pendidikan ingin diterima oleh masyarakat serta dapat terus eksis dan berkembang ditengah-tengah dukungan masyarakat.

Perguruan tinggi sebagai salah satu institusi pendidikan supaya akuntabel dan bermutu dituntut untuk memberikan pelayanan akademik yang berkualitas. Perguruan tinggi sebagai industri jasa harus mulai memikirkan pentingnya pelayanan pelanggan secara lebih matang, karena kini semakin disadari bahwa pelayanan dan kepuasan pelanggan merupakan aspek vital dalam rangka 
bertahan dalam bisnis dan memenangkan persaingan. Menurut Avianti dalam (Sufiyyah, 2011: 88) Kualitas adalah sesuatu yang dinamis terus ergerak, jika bergerak maju dikatakan ada peningkatan mutu, jika bergerak mundur dikatakan menurun mutunya. Kualitas dapat berarti superiority atau excellence yaitu melebihi standar umum yang berlaku. Sesuatu dapat dikatakan berkualitas jika terdapat kecocokan antara syarat-syarat yang dimilikioleh benda atau jasa yang menghendakinya. Bagian pelayanan akademik banyak berkaitan secara langsung dengan mahasiswa, sehingga layanan akademik tersebut perlu mendapatkan perhatian lebih agar dapat memberikan kepuasan optimal bagi mahasiswa. Kepuasan layanan menjadi sangat penting karena akan membantu peserta mahasiswa loyal kepada institusi, mahasiswa bersedia mempromosikan institusi tersebut kepada orang lain, meningkatkan animo masyarakat untuk melanjutkan pendidikan di institusi itu.

Bagi sebuah perguruan tinggi kepuasan akademik lebih diorientasikan kepada mahasiswa karena mahasiswa merupakan pelanggan utama. Menurut Sopiatin (2010:33) Kepuasan mahasiswa adalah sikap positif mahasiswa terhadap pelayanan lembaga pendidikan tinggi karena adanya kesesuaian antara harapan dari pelayanan dibandingkan dengan kenyataan yang diterima, sedangkan menurut Sugito dalam Rahayu (2013:4)mengungkapkan bahwa kepuasan mahasiswa adalah suatu keadaan dimana terpenuhinya keinginan, harapan, dan kebutuhan mahasiswa. Jika pelayanan yang diberikan dapat memenuhi keinginan, harapan, dan kebutuhan mahasiswa, maka dapat dinilai pelayanan itu memuaskan, dan sebaliknya, jika pelayanan yang diberikan tidak dapat memenuhi keinginan, harapan, dan kebutuhan mahasiswa maka dapat disimpulkan pelayanan itu tidak memuaskan.

Kepuasan mahasiswa dalam penelitian ini adalah kesesuaian antara harapan dan kinerja dari layanan akademik yang diterima oleh mahasiswa. Adapun indikator kepuasan mahasiswa dalam pelayanan akademik yang dimaksud antara lain bukti fisik, kehandalan, daya tanggap, jaminan dan empati. Politeknik Sawunggalih Aji (POLSA) merupakan salah satu perguruan tinggi yang berada di Kabupaten Purworejo, POLSA memiliki jumlah mahasiswa sebanyak 231 orang. Jumlah mahasiswa tersebut harus diimbangi dengan pemberian pelayanan yang baik, megikuti aturan akademik yang telah ditetapkan, sebagai dasar untuk dilaksanakan oleh seluruh civitas akademika yaitu staf administrasi, dosen, mahasiswa dan manajemen pengelola pendidikan ini. Untuk dapat mensinkronisasikan peraturan akademik tersebut dengan tujuan yang diharapkan diperlukan adanya komitmen yang kokoh dari masing-masing pihak yaitu mahasiswa, dosen, staf administrasi dan manajemen untuk melaksanakan dan mengevaluasi aktifitasnya sehingga tujuan dapat tercapai sesuai dengan visi dan misi lembaga ini. Prioritas dibidang pelayanan yang diberikan kepada mahasiswa tentunya adalah bidang pelayanan akademik.

Jasa pelayanan akademik yang berkualitas, diharapkan mampu memberikan kepuasan mahasiswa, dan mahasiswa penerima layanan dapat memberikan evaluasi atas jasa layanan yang diterimanya. Kedua belah pihak mempunyai hubungan timbal balik sehingga masing-masing pihak memperoleh kepuasan yang sama. Berkaitan dengan kepuasan pelayanan akademik, POLSA dipandang perlu mengevaluasi kegiatan pelayanan akademik tersebut untuk mengetahui bagaimana penilaian mahasiswa terhadap pelayanan yang diberikan. Karena pada kenyataannya masih ada keluhan dari mahasiswa mengenai kualitas layanan yang diberikan, misalnya kurangnya penyampaian informasi yang jelas, ketidak disiplinan pegawai seperti ketika jam istirahat selesai pegawai belum ada di ruangan, serta ruang pelayanan akademik yang terbatas sehingga ketika ada banyak mahasiswa yang membutuhkan pelayanan harus berdesak- desakan.

\section{METODE PENELITIAN}

Menurut Sugiyono (2011:2) Metode penelitian pada dasarnya merupakan suatu cara ilmiah untuk mendapatkan data-data dengan tujuan dan kegunaan tetentu". Dalam hal ini penulisan laporan Tugas Akhir ini, metode yang digunakan bersifat "Deskriptif" yaitu menggambarkan suatu objek berdasarkan fakta yang tampak apa adanya sesuai dengan kenyataan.

1. Jenis Data

a. Data Kualitatif

Data kualitatif adalah data yang mempunyai bentuk kalimat, kata atau gambar (Sugiyono, 2013:23). Pada metode ini penulis mengumpulkan data yang benar dengan melakukan wawancara kepada kepala bagian administrasi akademik Politeknik Sawunggalih Aji 
Purworejo.

b. Data Kuantatif

Data kuantitatif yaitu data yang bukan berbentuk kata melainkan data yang berbentuk angka atau data kualitatif yang diangkakan (Sugiyono,2013:23). Untuk mendapatkan data kuantitatif, penulis menggunakan kuesioner yang disebar pada mahasiswa dengan skala 1 sampai dengan 5.

2. Sumber Data

\section{a. Data Primer}

Data primer adalah sumber data yang memberikan data langsung kepada pengumpulan data. (Sugiyono, 2013:173). Dalam hal ini penulis memperoleh data informasi dengan mewawancarai langsung kepada kepala bagian akademik Politeknik Sawunggalih Aji Purworejo, untuk mendapatkan data tentang jumlah mahasisswa dan struktur organisasi.

b. Data Sekunder

Data sekunder adalah sumber data yang tidak langsung memberikan data kepada pengumpulan data" (Sugiyono, 2013:173). Dalam hal ini penulis memperoleh data informasi dari studi pustaka yang berkaitan dengan kualitas pelayanan akademik Politeknik Sawunggalih Aji Purworejo kepada mahasiswa.

3. Teknik Pengumpulan Data

a. Observasi

Observasi erupakan suatu pengumpulan data dimana peneliti melakukan pengamatan secara langsung ke objek penelitian untuk meihat dari dekat bagaimana kegiatan yang dilakukan oleh peneliti”, (Riduwan, 2014:104). Dalam hal metode ini penulis melakukan pengamatan langsung di bagian akademik Politeknik Sawunggalih Aji Purworejo.

b. Wawancara

Wawancara adalah "percakapan yang dilakukan oleh dua pihak yaitu pewawancara yang mengajukan pertanyaan dan terwawancara yang memberikan jawaban atas apa yang telah menjadi sebuah pertanyaan" (Moelong, 2009:186). Dalam metode ini penulis melakukan wawancara dengan karyawan akademik Politeknik Sawunggalih Aji Purworejo.

c. Studi Pustaka

Studi pustaka adalah teknik pengumpulan data dengan cara mempelajari, memenuhi sumber-sumber data yang ada pada beberapa buku terkait.

d. Kuesioner atau Angket

Kuesioner merupakan teknik pengumpulan data yang dilakukan dengan cara memberi seperangkat pertanyaan atau pernyataan tertulis kepada responden untuk dijawabnya (Sugiyono, 2010:199). Dalam hal ini penulis memberikan kuesioner kepada mahasiswa sejumlah 50 orang.

e. Dokumentasi

Dokumentasi merupakan catatan peristiwa yang sudah berlalu. Dokumentasi bisa berbentuk tulisan, gambar atau karya-karya monumental dari seseorang. Dokumentasi merupakan pelengkap dari penggunaan metode observasi dan wawancara dalam penelitian kualitatif. (Sugiyono, 2010:422).

\section{HASIL DAN PEMBAHASAN}

\section{Deskripsi Responden}

Deskripsi responden berdasarkan jenis kelamin.

Tabel 1. Deskripsi responden

\begin{tabular}{|c|c|c|c|}
\hline No. & Jenis Kelamin & Frekuensi & Presentase \\
\hline 1 & Laki-laki & 18 & $36 \%$ \\
\hline 2 & Perempuan & 32 & $64 \%$ \\
\hline \multicolumn{2}{|c|}{ Total } & 50 & $100 \%$ \\
\hline
\end{tabular}


Deskripsi responden berdasarkan program studi.

Tabel 2. Deskripsi responden

\begin{tabular}{|c|c|c|c|}
\hline No. & Program Studi & Frekuensi & Presentase \\
\hline 1 & TI & 18 & $36 \%$ \\
\hline 2 & AK & 13 & $26 \%$ \\
\hline 3 & AB & 19 & $38 \%$ \\
\hline \multicolumn{2}{|c|}{ Total } & 50 & $100 \%$ \\
\hline
\end{tabular}

\section{Hasil Kuesioner}

a. Jumlah kuesioner dan responden.

Dalam penelitian ini, penulis mengangkat permasalahan mengenai analisis kualitas pelayanan pada bagian akademik Politeknik Sawunggalih Aji. Untuk mengumpulkan data berupa informasi yang dibutuhkan, penulis menggunakan kuesioner yang disebar kepada 50 sampel mahasiswa aktif POLSA tahun akademik 2015 s.d. 2017. Berikut ini adalah tabel jumlah kuesioner yang berhubungan dengan penelitian.

Tabel 3. Jumlah kuesioner

\begin{tabular}{|c|c|}
\hline Keterangan & Jumlah \\
\hline Kuesioner yang disebar & 50 \\
\hline Kuesioner yang kembali & 50 \\
\hline Kuesioner yang tidak kembali & 0 \\
\hline
\end{tabular}

b. Variabel penelitian

Kualitas pelayanan yang diberikan mempunyai peran penting dalam menentukan kepuasan mahasiswa terhadap pelayanan itu sendiri. Banyak indikator yang dapat mempengaruhi tingkat kepuasan mahasiswa diantaranya yaitu bukti fisik, kehandalan, daya tanggap, jaminan dan empati. Untuk lebih jelasnya akan disajikan tanggapan responden melalui tabel frekuensi dimana frekuensi tiap variabel akan menjelaskan berapa banyak mahasiswa dan presentase mahasiswa yang sangat setuju (5), setuju (4), ragu-ragu (3), tidak setuju (2) dan sangat tidak setuju (1) dalam tiap pernyataan yang disajikan.

I. Bukti Fisik $\left(\mathrm{X}_{1}\right)$

Berdasarkan tanggapan responden mengenai variabel bukti fisik dari 50 responden, dengan indikator $X_{1.1}$ s.d. $X_{1.3}$ rata-rata memberikan jawaban setuju, dimana pada indikator pegawai berpenampilan rapi dan sopan sesuai dengan situasi dan kondisi mendapatkan jawaban sebesar $(60 \%)$ responden setuju, 9 (18\%) responden sangat setuju, 6 (12\%) ragu-ragu, $3(6 \%)$ tidak setuju dan $2(4 \%)$ sangat tidak setuju. Kemudian indikator ruang administrasi bersih dan tertata secara rapi yaitu sebanyak 29 (58\%) setuju, namun disisi lain tingkat keragu-raguan mahasiswa terhadap indikator ruang pelayanan administrasi nyaman masih cukup tinggi yaitu dengan jumlah 19 $(38 \%)$ responden.

II. Kehandalan $\left(\mathrm{X}_{2}\right)$

Berdasarkan tanggapan responden mengenai variabel kehandalan dari 50 responden, dengan indikator $X_{2.1}$ s.d. $X_{2.4}$ responden memberikan jawaban setuju dan ragu-ragu. Indikator yang paling banyak mendapatkan respon setuju adalah pegawai akademik memberikan pelayanan yang memuaskan sesuai dengan kebutuhan yaitu sebanyak 30 $(60 \%)$ responden, kemudian indikator prosedur pelayanan akademik tidak berbelit-belit juga cukup banyak mendapat jawaban setuju dari mahasiswa, yaitu sebesar 25 (50\%) responden. Adapun indikator yang memperoleh jawaban tingkat keraguan cukup tinggi yaitu kegiatan administrasi rapi dan teratur sebanyak 19 (38\%) responden.

III. Daya Tanggap $\left(\mathrm{X}_{3}\right)$

Berdasarkan tanggapan responden mengenai variabel daya tanggap dari 50 responden, dengan indikator $X_{3.1}$ s.d. $X_{3.6}$ responden memberikan jawaban sangat setuju dan setuju cukup banyak. Pada indikator pegawai akademik memiliki sifat sopan, ramah, jujur dan dapat dipercaya sebanyak $29(58 \%)$ responden memberikan jawaban setuju dan 11 
(22\%) responden memberikan jawaban sangat setuju. Berdasarkan tabel diatas dapat dilihat juga bahwa sebanyak tiga indikator memperoleh jawaban setuju yang sama yaitu sebanyak $25(50 \%)$ responden.

IV. Empati $\left(\mathrm{X}_{4}\right)$

Berdasarkan tanggapan responden mengenai variabel empati dari 50 responden, dengan indikator $\mathrm{X}_{4.1}$ s.d. $\mathrm{X}_{4.3}$, lebih dari $50 \%$ responden setuju bahwa akses pelayanan administrasi mudah adalah indikator yang paling mempengaruhi tingkat kepuasan mahasiswa yaitu sebanyak $30(60 \%)$ responden memberikan tanggapan setuju, $5(10 \%)$ responden sangat setuju tetapi $9(18 \%)$ masih ragu-ragu.Kemudian indikator pegawai akademik mempunyai kemampuan komunikasi yang baik juga mendapat tanggapan sebanyak $28(56 \%)$ responden memberikan jawaban setuju, $11(22 \%)$, sangat setuju, 8 (16\%) ragu-ragu, 1 (2\%) tidak setuju dan $2(4 \%)$ memberikan tanggapan sangat tidak setuju.

V. Jaminan $\left(\mathrm{X}_{5}\right)$

Berdasarkan tanggapan responden mengenai variabel jaminan dari 50 responden, dengan indikator $\mathrm{X}_{5.1}$ dan $\mathrm{X}_{5.2}$ sebanyak 25 (50\%) responden setuju bahwa dalam memberikan pelayanan bagian akademik mampu menyimpan data mahasiswa secara aman. Pada indikator yang kedua yaitu bagian akademik mampu menjaga kerahasiaan data mahasiswa, responden yang memberikan tanggapan sangat setuju cukup banyak yaitu $16(32 \%)$, kemudian $21(42 \%)$ setuju, $10(20 \%)$ ragu-ragu, $2(4 \%)$ tidak setuju dan $1(2 \%)$ sangat tidak setuju.

VI. Kepuasan mahasiswa (Y)

Berdasarkan tanggapan responden mengenai variabel kepuasan dari 50 responden, pada indikator Y1 "Saya puas dengan kecepatan dan ketepatan pelayanan yang diberikan oleh pegawai akademik" responden memberikan jawaban setuju sebesar 32 $(64 \%), 3(6 \%)$ sangat setuju, $7(14 \%)$ ragu-ragu, $6(12 \%)$ tidak setuju dan $2(4 \%)$ sangat tidak setuju. Pada indikator Y2 "Saya puas dengan kemampuan pelayanan yang diberikan oleh pegawai akademik" responden memberikan jawaban setuju sebesar 27 (54\%), 9 (18\%) sangat setuju, 10 (20\%) ragu-ragu, 4 (8\%) tidak setuju dan 0 pada pilihan sangat tidak setuju.

Pada indikator Y3 "Saya puas dengan keramahan yang dimiliki oleh pegawai akademik" responden memberikan jawaban setuju sebesar 28 (56\%), 7 (14\%) sangat setuju, 13 (26\%) ragu-ragu, 1 (2\%) dan $1(2 \%)$ sangat tidak setuju. Kemudian pada indikator Y4 "Saya puas dengan fasilitas yang ada pada bagian akademik" responden memberikan jawaban setuju sebesar 24 (48\%), 8 (16\%) sangat setuju, 14 (28\%) raguragu, $3(6 \%)$ dan $1(2 \%)$ sangat tidak setuju.

\section{Pengujian validitas, reliabilitas dan regresi linier beganda}

a. Uji Validitas

Uji validitas butir pernyataan untuk variabel bukti fisik (X1). Jika $r$ hitung lebih besar dari $r$ tabel dan bernilai positif, maka butir pernyataan atau indikator tersebut dinyatakan valid. Variabel bukti fisik (X1) terdiri dari tiga pernyataan. Hasil uji validitas butir pernyataan untuk variabel bukti fisik (X1) dengan menggunakan bantuan program SPSS Versi 21 dapat dilihat pada tabel berikut ini:

Tabel 4. Hasil Uji Validitas Bukti Fisik

\begin{tabular}{|c|c|c|c|c|}
\hline Variabel & No. Pernyataan & R hitung & R tabel & Kriteria \\
\hline Bukti fisik & X1.1 & 0,651 & 0,279 & Valid \\
\cline { 2 - 5 } & X1.2 & 0,761 & 0,279 & Valid \\
\cline { 2 - 5 } & X1.3 & 0,604 & 0,279 & Valid \\
\hline
\end{tabular}

Dari hasil uji validitas butir variabel bukti fisik (X1) menunjukkan bahwa tidak ada butiran yang gugur karena syarat terpenuhi yaitu nilai koefisien item total (Corrected Item Total 
Correlation) lebih dari 0,279 sehingga ketiga butir pernyataan variabel bukti fisik (X1) tersebut dinyatakan valid dalam menjelaskan variabelnya.

Validitas butir pernyataan untuk variabel reliability (X2) terdiri dari empat pernyataan. Hasil uji validitas butir pernyataan untuk variabel reliability $\left(\mathrm{X}_{2}\right)$ dengan menggunakan program SPSS 21 dapat dilihat pada tabel berikut ini:

Tabel 5. Hasil Uji Validitas Kehandalan

\begin{tabular}{|c|c|c|c|c|}
\hline Variabel & No. Pernyataan & R hitung & R tabel & Kriteria \\
\hline Kehandalan & X2.1 & 0,648 & 0,279 & Valid \\
\cline { 2 - 5 } & X2.2 & 0,716 & 0,279 & Valid \\
\cline { 2 - 5 } & X2.3 & 0,700 & 0,279 & Valid \\
\cline { 2 - 5 } & X2.4 & 0,713 & 0,279 & Valid \\
\hline
\end{tabular}

Dari hasil uji validitas butir variabel kehandalan (X2) menunjukkan bahwa tidak ada butiran yang gugur karena syarat terpenuhi yaitu nilai koefisien item total (Corrected Item Total Correlation) lebih dari 0,279 sehingga ketiga butir pernyataan variabel kehandalan (X2) tersebut dinyatakan valid dalam menjelaskan variabelnya.

Validitas butir pernyataan untuk variabel daya tanggap (X3) terdiri dari enam pernyataan. Hasil uji validitas butir pernyataan untuk variabel daya tanggap (X3) dengan menggunakan program SPSS 21 dapat dilihat pada tabel berikut ini:

Tabel 6. Hasil Uji Validitas Daya Tanggap

\begin{tabular}{|c|c|c|c|c|}
\hline Variabel & No. Pernyataan & R hitung & R tabel & Kriteria \\
\hline Daya Tanggap & X3.1 & 0,761 & 0,279 & Valid \\
\cline { 2 - 5 } & X3.2 & 0,797 & 0,279 & Valid \\
\cline { 2 - 5 } & X3.3 & 0,724 & 0,279 & Valid \\
\cline { 2 - 5 } & X3.4 & 0,796 & 0,279 & Valid \\
\cline { 2 - 5 } & X3.5 & 0,744 & 0,279 & Valid \\
\cline { 2 - 5 } & X3.6 & 0,768 & 0,279 & Valid \\
\hline
\end{tabular}

Dari hasil uji validitas butir variabel daya tanggap (X3) menunjukkan bahwa tidak ada butiran yang gugur karena syarat terpenuhi yaitu nilai koefisien item total (Corrected Item Total Correlation) lebih dari 0,279 sehingga keenam butir pernyataan variabel daya tanggap (X3) tersebut dinyatakan valid dalam menjelaskan variabelnya.

Validitas butir pernyataan untuk variabel empati (X4) terdiri dari tiga pernyataan. Hasil uji validitas butir pernyataan untuk variabel empati (X4) dengan menggunakan program SPSS 21 dapat dilihat pada tabel berikut ini:

Tabel 7. Hasil Uji Validitas Empati

\begin{tabular}{|c|c|c|c|c|}
\hline Variabel & No. Pernyataan & R hitung & R tabel & Kriteria \\
\hline \multirow{3}{*}{ Empati } & $\mathrm{X} 4.1$ & 0,736 & 0,279 & Valid \\
\cline { 2 - 5 } & $\mathrm{X} 4.2$ & 0,820 & 0,279 & Valid \\
\cline { 2 - 5 } & $\mathrm{X} 4.3$ & 0,866 & 0,279 & Valid \\
\hline
\end{tabular}

Dari hasil uji validitas butir variabel empati (X4) menunjukkan bahwa tidak ada butiran yang gugur karena syarat terpenuhi yaitu nilai koefisien item total (Corrected Item Total Correlation) lebih dari 0,279 sehingga ketiga butir pernyataan variabel emphaty (X4) tersebut dinyatakan valid dalam menjelaskan variabelnya.

Validitas butir pernyataan untuk variabel jaminan (X5) terdiri dari dua pernyataan. Hasil uji validitas butir pernyataan untuk variabel jaminan (X5) dengan menggunakan program SPSS 21 dapat dilihat pada tabel berikut ini: 
Tabel 8. Hasil Uji Validitas Jaminan

\begin{tabular}{|c|c|c|c|c|}
\hline Variabel & No. Pernyataan & R hitung & R tabel & kriteria \\
\hline \multirow{2}{*}{ Jaminan } & X5.1 & 0,715 & 0,279 & Valid \\
\cline { 2 - 5 } & X5.2 & 0,733 & 0,279 & Valid \\
\hline
\end{tabular}

Dari hasil uji validitas butir variabel jaminan (X5) menunjukkan bahwa tidak ada butiran yang gugur karena syarat terpenuhi yaitu nilai koefisien item total (Corrected Item Total Correlation) lebih dari 0,279 sehingga kedua butir pernyataan variabel jaminan (X5) tersebut dinyatakan valid dalam menjelaskan variabelnya.

Validitas butir pernyataan untuk variabel kepuasan mahasiswa (Y) terdiri dari empat pernyataan. Hasil uji validitas butir pernyataan untuk variabel kepuasan mahasiswa (Y) dengan menggunakan program SPSS 21 dapat dilihat pada tabel berikut ini:

Tabel 9. Hasil Uji Validitas Kepuasan Mahasiswa

\begin{tabular}{|c|c|c|c|c|}
\hline Variabel & No. Pernyataan & R hitung & R tabel & Kriteria \\
\hline \multirow{3}{*}{$\begin{array}{c}\text { Kepuasan } \\
\text { mahasiswa }\end{array}$} & Y1 & 0,776 & 0,279 & Valid \\
\cline { 2 - 5 } & Y2 & 0,809 & 0,279 & Valid \\
\cline { 2 - 5 } & Y3 & 0,743 & 0,279 & Valid \\
\cline { 2 - 5 } & Y4 & 0,691 & 0,279 & Valid \\
\hline
\end{tabular}

Dari hasil uji validitas butir variabel kepuasan mahasiswa (Y) menunjukkan bahwa tidak ada butiran yang gugur karena syarat terpenuhi yaitu nilai koefisien item total (Corrected Item Total Correlation) masing-masing indikator lebih dari 0,279 sehingga keempat butir pernyataan variabel kepuasan mahasiswa (Y) tersebut dinyatakan valid dalam menjelaskan variabelnya.

b. Uji Reliabilitas

Uji reliabilitas ini digunakan untuk mengetahui konistensi alat ukur, apakah alat ukur yang digunakan dapat diandalkan dan tetap konsisten apabila pengukuran tersebut diulang.

Metode reliabilitas yang digunakan oleh penulis adalah metode Cronbach's Alpha. Dimana untuk menentukan instrumen tersebut reliabel atau tidak bisa digunakan batasan tertentu seperti 0,6. Menurut Sekaran dalam Priyatno (2016:60), reliabilitas kurang dari 0,6 adalah kurang baik, sedangkan 0,7 dapat diterima dan diatas 0,8 adalah baik. Adapun hasil uji reliabilitas terhadap analisis kualitas pelayanan mahasiswa pada bagian akademik POLSA, adalah sebagai berikut:

Tabel 10. Hasil Uji Reliabilitas Bukti Fisik Reliability Statistics

\begin{tabular}{|l|l|}
\hline $\begin{array}{l}\text { Cronbach's } \\
\text { Alpha }\end{array}$ & N of Items \\
\hline 840 & 3 \\
\hline
\end{tabular}

Berdasarkan hasil uji reliabilitas di atas, dapat diketahui nilai reliabilitas (Cronbach's Alpha) variabel tangible (X1) sebesar 0,840 sedangkan nilai konstanta adalah 0,6. Maka dapat disimpulkan bahwa variabel $\mathrm{X} 1$ reliabel dan dapat dikatakan baik karena nilai Cronbach's Alpha lebih besar dari nilai konstantanya dan lebih besar dari 0,8. 
Tabel 11. Hasil Uji Reliabilitas Kehandalan

Reliability Statistics

\begin{tabular}{|l|l|}
\hline $\begin{array}{l}\text { Cronbach's } \\
\text { Alpha }\end{array}$ & N of Items \\
\hline 833 & 4 \\
\hline
\end{tabular}

Berdasarkan hasil uji reliabilitas di atas, dapat diketahui nilai reliabilitas (Cronbach's Alpha) variabel kehandalan (X2) sebesar 0,833 sedangkan nilai konstanta adalah 0,6. Maka dapat disimpulkan bahwa variabel $\mathrm{X}_{2}$ reliabel dan dapat dikatakan baik karena nilai Cronbach's Alpha lebih besar dari nilai konstantanya dan lebih besar dari 0,8.

Tabel 12. Hasil Uji Reliabilitas Daya Tanggap

Reliability Statistics

\begin{tabular}{|l|l|}
\hline $\begin{array}{l}\text { Cronbach's } \\
\text { Alpha }\end{array}$ & N of Items \\
\hline 897 & 6 \\
\hline
\end{tabular}

Berdasarkan hasil uji reliabilitas di atas, dapat diketahui nilai reliabilitas (Cronbach's Alpha) variabel daya tanggap (X3) sebesar 0,897 sedangkan nilai konstanta adalah 0,6. Maka dapat disimpulkan bahwa variabel X3 reliabel dan dapat dikatakan baik karena nilai Cronbach's Alpha lebih besar dari nilai konstantanya dan lebih besar dari 0,8.

Tabel 13. Hasil Uji Reliabilitas Empati

Reliability Statistics

\begin{tabular}{|l|l|}
\hline $\begin{array}{l}\text { Cronbach's } \\
\text { Alpha }\end{array}$ & N of Items \\
\hline 859 & 3 \\
\hline
\end{tabular}

Berdasarkan hasil uji reliabilitas di atas, dapat diketahui nilai reliabilitas (Cronbach's Alpha) variabel empati (X4) sebesar 0,897 sedangkan nilai konstanta adalah 0,6. Maka dapat disimpulkan bahwa variabel $\mathrm{X} 4$ reliabel dan dapat dikatakan baik karena nilai Cronbach's Alpha lebih besar dari nilai konstantanya dan lebih besar dari 0,8.

Tabel 14. Hasil Uji Reliabilitas Jaminan

Reliability Statistics

\begin{tabular}{|l|l|}
\hline $\begin{array}{l}\text { Cronbach's } \\
\text { Alpha }\end{array}$ & N of Items \\
\hline 882 & 2 \\
\hline
\end{tabular}

Berdasarkan hasil uji reliabilitas di atas, dapat diketahui nilai reliabilitas (Cronbach's Alpha) variabel jaminan (X5) sebesar 0,882 sedangkan nilai konstanta adalah 0,6. Maka dapat disimpulkan bahwa variabel X5 reliabel dan dapat dikatakan baik karena nilai Cronbach's Alpha lebih besar dari nilai konstantanya dan lebih besar dari 0,8. 
Tabel 15. Hasil Uji Reliabilitas Kepuasan Mahasiswa

Reliability Statistics

\begin{tabular}{|l|l|}
\hline $\begin{array}{l}\text { Cronbach's } \\
\text { Alpha }\end{array}$ & N of Items \\
\hline 846 & 4 \\
\hline
\end{tabular}

Berdasarkan hasil uji reliabilitas di atas, dapat diketahui nilai reliabilitas (Cronbach's Alpha) variabel kepuasan mahasiswa (Y) sebesar 0,846 sedangkan nilai konstanta adalah 0,6. Maka dapat disimpulkan bahwa variabel Y reliabel dan dapat dikatakan baik karena nilai Cronbach's Alpha lebih besar dari nilai konstantanya dan lebih besar dari 0,8.

c. Uji Regresi Linier Berganda

Hasil dari pengolahan data untuk analisis regresi liniar berganda dalam penelitian analisis kualitas pelayanan mahasiswa pada bagian akademik POLSA adalah sebagai berikut:

Tabel 16. Hasil R Square

Model Summary

\begin{tabular}{|c|c|c|c|c|}
\hline Model & $\mathrm{R}$ & R Square & $\begin{array}{c}\text { Adjusted R } \\
\text { Square }\end{array}$ & $\begin{array}{c}\text { Std. Error of } \\
\text { the Estimate }\end{array}$ \\
\hline 1 & $\begin{array}{c}, 884 \\
\mathrm{a}\end{array}$ &, 781 &, 756 & 1,403 \\
\hline
\end{tabular}

a. Predictors: (Constant), x5, x2, x1, x4, x3

Berdasarkan hasil analisis determinasi di atas, nilai $\mathrm{R}$ sebesar 0,884 atau 88,4\% menunjukkan korelasi antara seluruh variabel bebas dengan variabel terikat. Nilai R Square (R kuadrat/ $\mathrm{R}^{2}$ ) menunjukkan koefisien determinasi yaitu sebesar 0,781 atau 78,1\%. Hal itu dapat diartikan 78,1\% jumlah presentase kontribusi variabel bebas (bukti fisik, kehandalan, daya tanggap, empati dan jaminan) kepada variabel terikat (kepuasan mahasiswa). Sedangkan sisanya $21,9 \%$ disebabkan oleh faktor lain.

Nilai dari Adjusted $R$ Square adalah 0,756 nilai tersebut berarti kemampuan variabel bebas dalam menjelaskan varians dari variabel terikatnya adalah sebesar 75,6\%.

Tabel 17. Hasil Analisis Uji F ANOVA $^{\mathrm{a}}$

\begin{tabular}{|c|c|c|c|c|c|c|}
\hline & Model & $\begin{array}{l}\text { Sum of } \\
\text { Squares }\end{array}$ & $\mathrm{df}$ & Mean Square & $\mathrm{F}$ & Sig. \\
\hline & Regression & 309,385 & 5 & 61,877 & 31,426 &, $000^{b}$ \\
\hline 1 & Residual & 86,635 & 44 & 1,969 & & \\
\hline & Total & 396,020 & 49 & & & \\
\hline
\end{tabular}

Berdasarkan hasil analisis uji $\mathrm{F}$ di atas, diperoleh $\mathrm{F}$ hitung sebesar 31,426 dengan $\mathrm{F}$ tabel sebesar 2,427 yang diperoleh dengan menggunakan tingkat signifikansi 0,05 dengan df 1 (jumlah variabel -1 atau 6-1 =5) dan df $2=n-k-1$ (jumlah data-jumlah variabel bebas-1 atau 50-5-1 = 44). Hal tersebut dapat diartikan bahwa Fhitung > Ftabel atau 31,426 > 2,427, maka Ha (Hipotesis) diterima, artinya variabel bukti fisik, kehandalan, daya tanggap, empati dan jaminan secara bersama-sama berpengaruh terhadap kepuasan 
mahasiswa.

Sedangkan nilai signifikansi dari hasil uji $\mathrm{F}$ adalah 0,000 dimana nilainya lebih kecil dari signifikansi 0,05, maka dapat disimpulkan bahwa variabel independen berpengaruh secara signifikan terhadap kepuasan mahasiswa.

Tabel 18. Hasil Uji Koefisien Regresi

Coefficients $^{\mathrm{a}}$

\begin{tabular}{|c|c|c|c|c|c|}
\hline & \multicolumn{4}{|c|}{ Coefficients ${ }^{\mathrm{a}}$} & \\
\hline \multirow[t]{2}{*}{ Model } & \multicolumn{2}{|c|}{$\begin{array}{l}\text { Unstandardized } \\
\text { Coefficients }\end{array}$} & $\begin{array}{c}\text { Standardized } \\
\text { Coefficients }\end{array}$ & $\mathrm{t}$ & \multirow[t]{2}{*}{ Sig. } \\
\hline & $B$ & Std. Error & Beta & & \\
\hline $\begin{array}{l}\text { (Const } \\
\text { ant) }\end{array}$ & 1,276 & 1,172 & & 1,089 & ,282 \\
\hline$x 1$ & , 195 & ,122 & 162 & 1,604 & , 116 \\
\hline$x 2$ & ,093 & ,127 & ,096 & ,736 & ,466 \\
\hline$x 3$ & ,077 & ,105 & ,126 & ,736 & ,466 \\
\hline$x 4$ & ,508 & ,172 & ,418 & 2,953 & ,005 \\
\hline$\times 5$ & ,340 & ,174 & ,211 & 1,954 & ,057 \\
\hline
\end{tabular}

Kepuasan mahasiswa $=1,276+0,195$ bukti fisik $+0,093$ kehandalan $+0,077$ daya tanggap $+0,508$ empati $+0,340$ jaminan

Interpretasi dari regreai di atas adalah sebagai berikut:

Nilai konstanta 1,276 ini berarti jika semua variabel bebas memiliki nilai 0 (nol) maka variabel terikat (Beta) sebesar 1,276. Nilai koefisien variabel $\mathrm{X} 1$ mempunyai pengaruh yang positif terhadap variabel $\mathrm{Y}$ sebesar 0,195 , artinya setiap kenaikan variabel X1 satu satuan maka variabel Beta (Y) akan naik sebesar 0,195. Nilai koefisien variabel X2 mempunyai pengaruh yang positif terhadap variabel $\mathrm{Y}$ sebesar 0,093, artinya setiap kenaikan variabel X2 satu satuan maka variabel Beta (Y) akan naik sebesar 0,093. Nilai koefisien variabel $\mathrm{X} 3$ mempunyai pengaruh yang positif terhadap variabel $\mathrm{Y}$ sebesar 0,077, artinya setiap kenaikan variabel X3 satu satuan maka variabel Beta (Y) akan naik sebesar 0,077 . Nilai koefisien variabel $\mathrm{X} 4$ mempunyai pengaruh yang positif terhadap variabel Y sebesar 0,508, artinya setiap kenaikan variabel X4 satu satuan maka variabel Beta akan naik sebesar 0,508. Nilai koefisien variabel X5 mempunyai pengaruh yang positif terhadap variabel Y sebesar 0,340, artinya setiap kenaikan variabel X5 satu satuan maka variabel Beta (Y) akan naik sebesar 0,340.

Adapun hasil uji $\mathrm{T}$, yang diperoleh dari uji analisis koefisien regresi dimana $\mathrm{A}=5 \%: 2=$ 2,5\% (uji 2 sisi) dengan kebebasan (df) n-k-1 atau 50-5-1 = 44 maka tabel dengan pengujian dua sisi (signifikansi 0,025) hasil diperoleh ttabel sebesar 2,015. Untuk mengetahui ada atau tidaknya pengaruh dari masing-masing variabel bebas maka nilai thitung dibandingkan dengan ttabel. Dari hasil tersebut dapat diketahui bahwa variabel bukti fisik memiliki thitung < tabel yaitu 1,604<2,015 dan nilai signifikansi 0,116>0,005 yang diartikan bahwa secara parsial variabel bukti fisik tidak berpengaruh signifikan terhadap kepuasan mahasiswa. Pada variabel kehandalan memiliki thitung $<$ ttabel yaitu $0,736<2,015$ dan nilai signifikansi $0,466>0,005$ yang diartikan bahwa variabel secara parsial kehandalan tidak berpengaruh signifikan terhadap kepuasan mahasiswa. Kemudian variabel daya tanggap memiliki thitung < tabel yaitu $0,736<2,015$ dan nilai signifikansi 0,466>0,005 yang diartikan bahwa variabel secara parsial daya tanggap tidak berpengaruh signifikan terhadap kepuasan mahasiswa. Pada variabel empati memiliki thitung $>$ tabel yaitu 2,953 >2,015 dan nilai signifikansi $0,005<0,005$ yang diartikan bahwa variabel secara 
parsial empati berpengaruh signifikan terhadap kepuasan mahasiswa. Dan pada variabel jaminan memiliki thitung < ttabel yaitu $1,954<2,015$ dan nilai signifikansi 0,057>0,005 yang diartikan bahwa variabel secara parsial jaminan tidak berpengaruh signifikan terhadap kepuasan mahasiswa.

\section{KESIMPULAN}

Berdasarkan pembahasan mengenai analisis kualitas pelayanan pada bagian akademik Politeknik Sawunggalih Aji, maka dapat disimpulkan bahwa:

1. Hasil uji t, variabel bukti fisik tidak berpengaruh signifikan terhadapat kepuasan mahasiswa. Hal ini dikarenakan nilai thitung < ttabel yaitu $-1,604<2,015$, nilai signifikansi > nilai alpha $0,05(0,116>0,05)$.

2. Hasil uji t, variabel kehandalan tidak berpengaruh signifikan terhadapat kepuasan mahasiswa. Hal ini dikarenakan nilai thitung < tabel yaitu $0,736<2,015$, nilai signifikansi > nilai alpha $0,05(0,466>0,05)$.

3. Hasil uji t, variabel daya tanggap tidak berpengaruh signifikan terhadapat kepuasan mahasiswa. Hal ini dikarenakan nilai thitung < tabel yaitu $0,736<2,015$, nilai signifikansi > nilai alpha $0,05(0,466>0,05)$.

4. Hasil uji t, variabel empati berpengaruh signifikan terhadapat kepuasan mahasiswa. Hal ini dikarenakan nilai thitung > ttabel yaitu 2,953 >2,015, nilai signifikansi 0,005.

5. Hasil uji t, variabel jaminan tidak berpengaruh signifikan terhadapat kepuasan mahasiswa. Hal ini dikarenakan nilai thitung < ttabel yaitu $1,954<2,015$, nilai signifikansi > nilai alpha 0,05 $(0,057>0,05)$.

6. Hasil uji t, faktor paling dominan adalah variabel empati. Hal ini dikarenakan nilai thitung lebih besar dari 2,015 dan nilai signifikansi 0,05 .

7. Hasil uji analisis determinasi yaitu sebesar $78,1 \%$ kontribusi variabel bebas terhadap variabel terikat dan 21,9\% disebabkan oleh faktor lain.

8. Hasil analisis uji $\mathrm{F}$ diperoleh Fhitung $>$ Ftabel yaitu 31,426>2,427 dan nilai signifikansi uji $\mathrm{F}$ 0,000 maka Ha (hipotesis) diterima artinya variabel bebas secara bersama-sama berpengaruh terhadap variabel terikat.

9. Hasil uji analisis koefisien regresi diperoleh persamaan regresi sebagai berikut: Kepuasan mahasiswa $=1,276+0,195$ bukti fisik $+0,093$ kehandalan $+0,077$ daya tanggap + 0,508 empati $+0,340$ jaminan

\section{SARAN}

Berdasarkan pembahasan mengenai analisis kualitas pelayanan pada bagian akademik Politeknik Sawunggalih Aji, maka ada beberapa hal yang perlu diperbaiki agar kualitas pelayanan yang diberikan menjadi lebih baik lagi kedepannya. Beberapa saran yang dapat penulis berikan antara lain:

1. Jumlah kuesioner hanya 50, maka untuk peneliti selanjutnya harus lebih banyak lagi.

2. Dalam kaitannya indikator kualitas pelayanan bukti fisik, perlu adanya peningkatan fasilitas pelayanan akademik seperti penambahan tempat untuk pelayanan mahasiswa.

3. Dalam kaitannya indikator kualitas pelayanan kehandalan, perlu adanya peningkatan kemampuan karyawan dalam memberikan pelayanan akademik, misalnya diberikan pelatihan tentang pelayanan konsumen.

4. Dalam kaitannya indikator kualitas pelayanan daya tanggap, perlu adanya peningkatan kecepatan dan ketepatan pelayanan akademik, misalnya ketika ada mahasiswa yang datang pegawai langsung menghampiri dan menanyakan apa yang dibutuhkan oleh mahasiswa.

\section{DAFTAR PUSTAKA}

Alwi, Hasan dkk. (2007). Kamus Besar Bahasa Indonesia. Edisi Ketiga : Yogyakarta.

Arikunto, Suharsimi. (2013). Prosedur Penelitian Suatu Pendekatan Praktik. Cetakan Ke-15. RinekaCipta: Jakarta

Hardyansyah. (2011). Kualitas Pelayanan Publik. Gava Media :Yogyakarta. 
Moelong. (2009). Metode Penelitian Kualitatif dan Kuantitatif. $\quad$ PT Remaja Rosdakaya: Bandung. Priyatno, Duwi. (2016). Belajar Alat Analisis Data Dan Cara Pengolahannya Dengan SPSS Praktis dan Mudah Dipahami untuk Tingkat Pemula dan Menengah. Gava Media:Yogyakarta.

Ratminto.(2015) . Manajemen Pelayanan Prima. CV Andi Offset:Yogyakarta.

Riduwan.( 2014). Pemasaran Jasa. CV Andi Offset : Yogyakarta.

Sopiatin, Popi. (2010). Manajemen Belajar Berbasis Kepuasan Siswa. Ghalia Indonesia : Bogor.

Sugiyono. (2013). Metode Penelitian Administrasi. CV Alfabeta : Bandung.

Sugiyono. (2011). Metode Penelitian Puantitatif Kualitatif dan R\&D. Alfabeta:Bandung.

Sunyoto, Danang. (2013). Dasar- Dasar Manajemen Pemasaran. CAPS: Yogyakarta. 